症例

進行性肺癌における大動脈合併切除と血行再建

\begin{tabular}{|c|c|c|c|c|c|c|c|c|c|c|}
\hline \multicolumn{11}{|c|}{ 岡山大学医学部第 2 外科 } \\
\hline 青 & 水 & 廣 & 久 & 保 & 義 & 郎 & 岡 & 野 & 和 & \\
\hline & 前 & 大 & 今 & 脇 & 節 & 朗 & 今 & 吉 & 英 & \\
\hline & 藤 & 悟 & 清 & 水 & 信 & 義 & 内 & 田 & 墢 & \\
\hline & 本 & 滋 & & & & & & & & \\
\hline
\end{tabular}

胸部大動脈に浸潤を有する進行性肺癌に対して，一時的バイバス下に大動脈合併切除 と血行再建を行い，良好な手術成績をえた 2 症例と経験したので報告する.

症例 1 は62藏男性, 左肺門部腫瘤で主気管支狭窄と下葉の無気肺を有し，胸部 CT 上 大動脈への浸潤が強く疑われた。. 左肺全葉切除とともに大動脈合併切除を行い,ダクロ ングラフト移植を行った，病理組織所見は，扁平上皮癌で，中膜までの浸潤を認めた。 術後経過は良好であったが，術後12力月目に急性肺炎で死亡した。

症例 2 は64歳男性, 左上葉に腫瘤を有し, 胸部 CT 上大動脈漫潤が疑われた。左上葉 切除とともに大動脈と左鎖骨下動脈の基始部を合併切除し，大動脈は直接端々吻合によ り血行再建した。病理組織所見は，腺癌で浸潤は外膜に限定していた。術後経過は良好 で，9カ月経過した現在も元気で日常生活を送っている。

進行性肺癌で大動脈に浸潤があっても, 根治性が期待でき準治瘾切除が可能な症例に 対しては，積極的に大動脈合併切除を試みてもいいと考劣る。

索引用語：進行性肺癌, 大動脈合併切除, 血行再建

はじめに

今日，腫煬外科の一般的㽞勢は上り根治性をたかめ る目的で、リンバ節郭清を伴 5 広沉切除を行い，隣接 臓器に浸潤を有する進行性悪性腫場に対しても, 積極 的に合併切除を行う傾向にある。 また，血管外科の進 步と発展に伴い, 従来は根治手術の適応外とされてい た主要血管への浸潤を有する症例に対しても，合併切 除を行った報告がみられるよらになった。しかし，進 行性肺癌で大動脈に浸潤を有する症例に対して, 合併 切除を行った報告は極めて少ない。今回，我々は大動 脈に浸潤を有する進行性肺癌症例において, 大動脈を 合併切除し血行再建を行った 2 例を経験したので, 若 干の文献的考察を加えて報告する。

\section{症 例}

症例 $1: 62$ 歳, 男性.

慢性肝炎にて某病院に入院加療中, 昭和57年 9 月, 発熱・咳濑・胸部痛の肺炎症状が出現し, 治療により

昭和 60 年 8 月 15 日受付 60 年11月 7 日採用
咳濑を残すのみで軽快したが，胸部 X線上，左下葉の 無気肺が残存したままであった。同年12月頃より嗄声 が出現し，食欲不振，体重诚少をきたすよらになった。 気管支鏡検査を行ったところ，左主気管支ははぼ全腔 腫堭により占められ，気管支分岐部にまで浸潤してい た。手術適応はないと言われて，しばらく対症療法の み受けていたか，昭和58年 3 月17日，当科へ再娭査と 手術適応の再検討のため転院した。

入院時現症は, 軽度の発熱と聴診上左胸部の呼吸音 の减弱を認める以外，特に異常所見は認めなかった。

入院時検查では，白血球数増多，赤沈值六進，呼吸 機能の軽度の低下を認めた。

胸部 X線写真では, 肺門部の腫瘤陰影と左下葉の無 気肺を認め，断層写真では，左主気管支が腫癒により 取り囲まれ狭窄像を呈していた（图 1).胸部 CTでは， 腫痹は大動脈に瘜着しており一部で境界不明で，大動 脈壁への浸潤が疑われた（図 2 ）。

術前放射線照射により狭窄症状が著明に改善したた め, 昭和58年 4 月 3 日手術を施行した. 


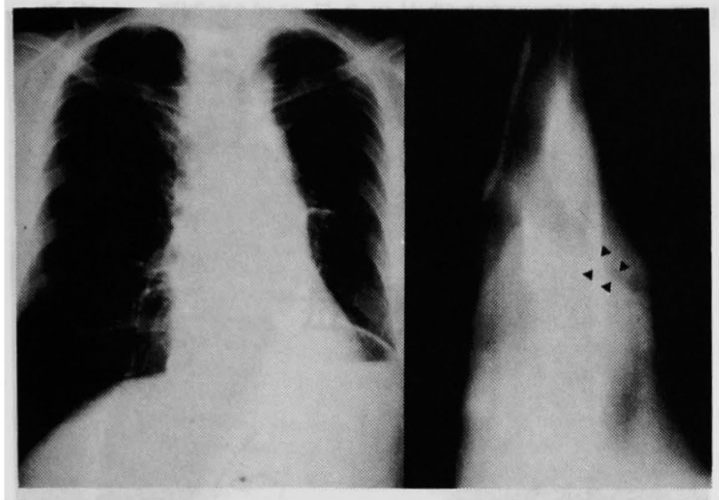

图 1 胸部X線写真では，肺門部に腫瘤陰影を認め, 左下肺の無気肺, 左横隔膜举上を有し, 断層写真で は，左主気管支の狭窄（矢印）を認めた。

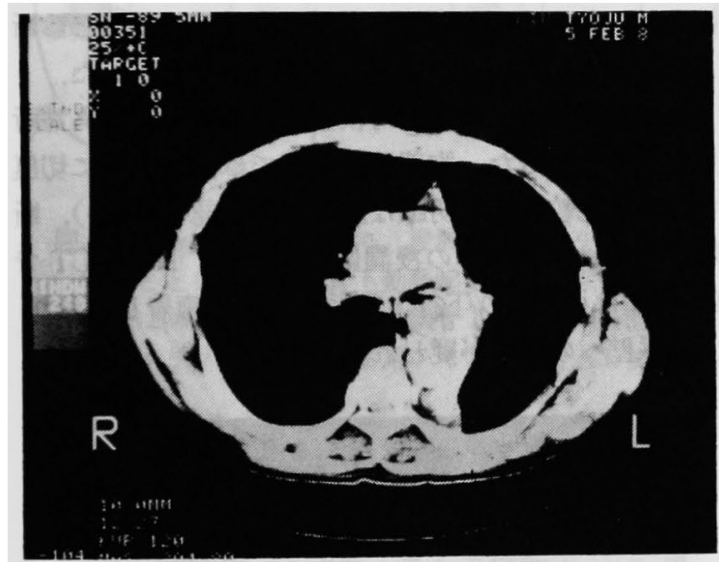

图 2 畽瘤は，下行大動脈に㦄着しており，一部で境 界不明であり，大動脈壁への浸潤が疑われる。

左後側方切開により，第 4 助間で開胸した。畽瘍は 肺門部からボタロー氏管リンバ節を経て，大動脈壁に 強固に空着し，一塊となっていた。

手術は，心膜を切開し，上・下肺静脈につついて左 肺動脈幹を処置した後, 左主気管支を切離し, 左肺全 摘を行った，次いで，左鎖骨下動脈から横隔膜直上の 下行大動脈に内径 $10 \mathrm{~mm}$ の Woven Dacron グラフト を用いて一時的パイハスを作製した. 左鎖骨下動脈分 枝直後の下行大動脈を $7 \mathrm{~cm}$ にわたって管状切離し, 左 肺とともにen blocに切除した. 下行大動脈は, 内径 20mmの Woven Dacron グラフトにて血行再建した (図3, 図4).

切除標本では, 大動脈壁への漫潤範囲は $5 \times 1.5 \mathrm{~cm}$ で強固に浸潤していたが，内腔への浸潤は認めなかっ た。また, 病理組織所見では, 腫瘍は扁生上皮滛で,

\section{症例 1}

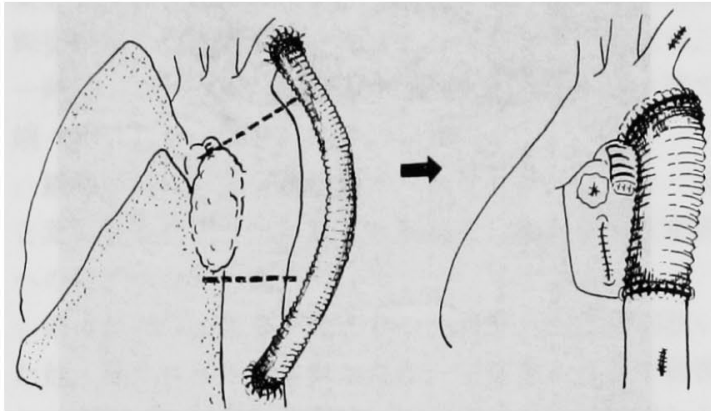

図 3 一時的ハイバス下に，浸潤部大動脈を管状切除 し, 内径 $20 \mathrm{~mm}$ の Wover Dacron グラフトを移植し た.

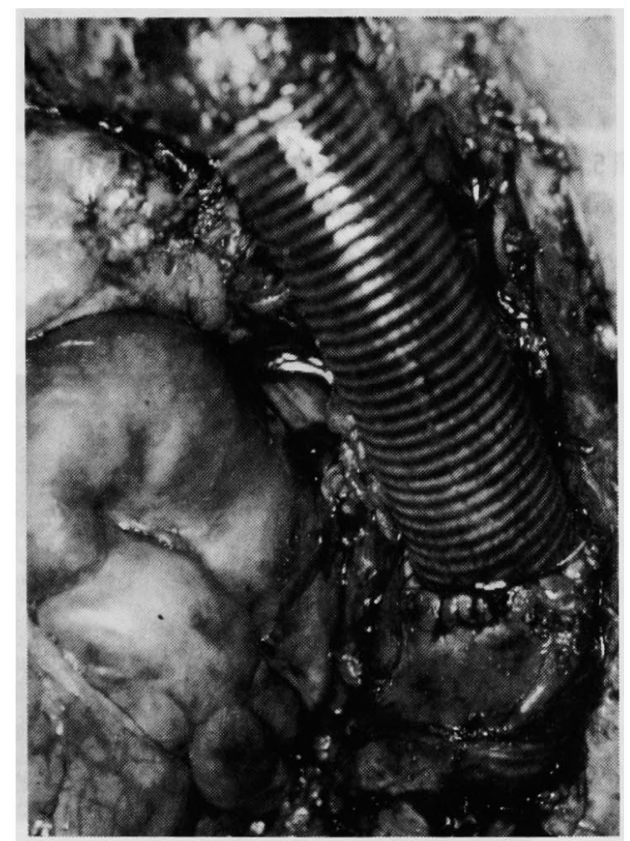

图 4 人工血管移植後の術中写真を示す、

ボタロー氏管リンパ節以外へのリンバ節転移は認めな かったが，大動脈壁の外膜への浸潤がみられ，一部は 中膜まで達していた（図5）。

術後经過は，6日目頃より間歇性発熱がしばらく続 いたが，強力な抗生物質投与により軽块し，労作時の 呼吸困難を軽度に残すのみで，昭和58年 7 月 15 日退院 した．退院後の経過る比較的順調であったが，術後約 1 年目に，肺炎による急性呼吸不全により死亡した。 症例 $2 ： 64$ 歳, 男性. 


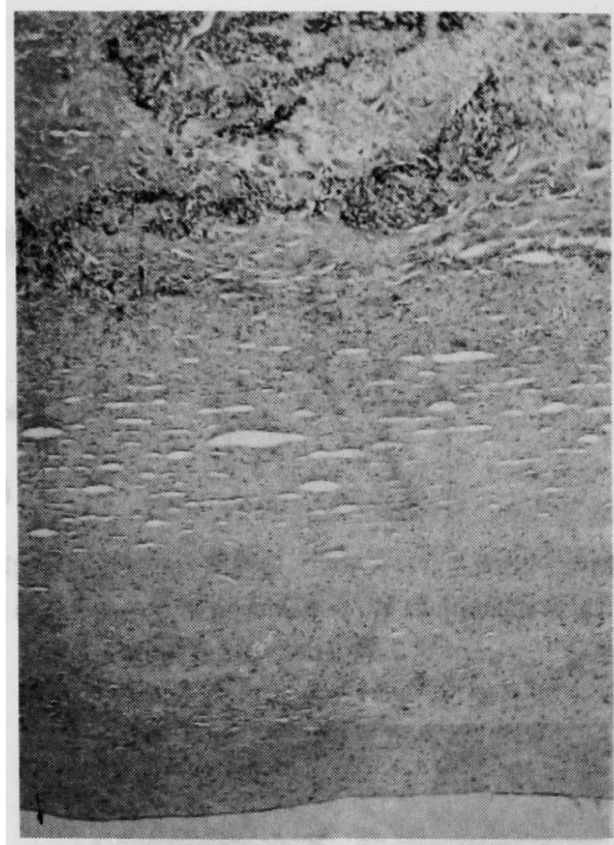

图 5 組織診断は扁平上皮癌で, 大動脈壁の外膜に浸 潤し，一部では中膜にまで達している。

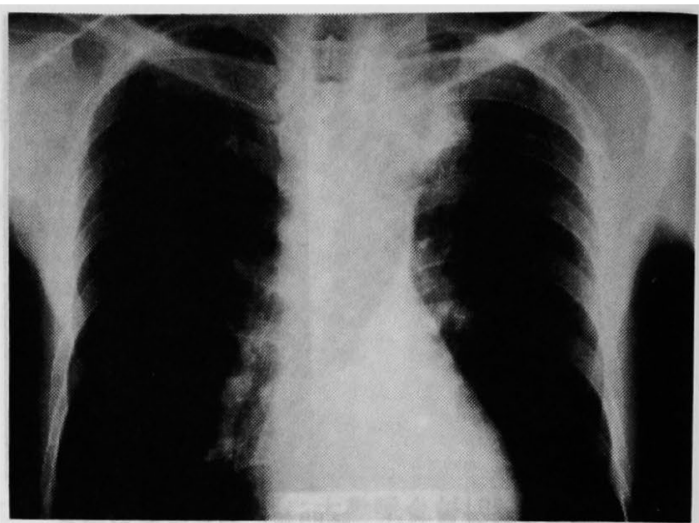

図6 左上葉に比較的境界明瞭な腫瘤陰影を認める.

昭和59年 8 月 31 日, 集団検診にて肺の異常陰影を指 摘され，某病院で精密検查を受けた結果，肺癌と診断 され，同年10月13日，当科へ手術目的で入院した。

入院時現症および入院時検査成績には，特に異常所 見を認めなかった。胸部X線写真では，左上葉に切痕 を有する比較的境界明瞙な隀瘤陰影を認め(図 6)，断 層写真では，綎隔への漫潤像を呈した。 NMR-CTで は、尰瘤は弓部より下行大動脈にかけて㦄着しており， 大動脈壁への浸洞が疑われた（図７）.
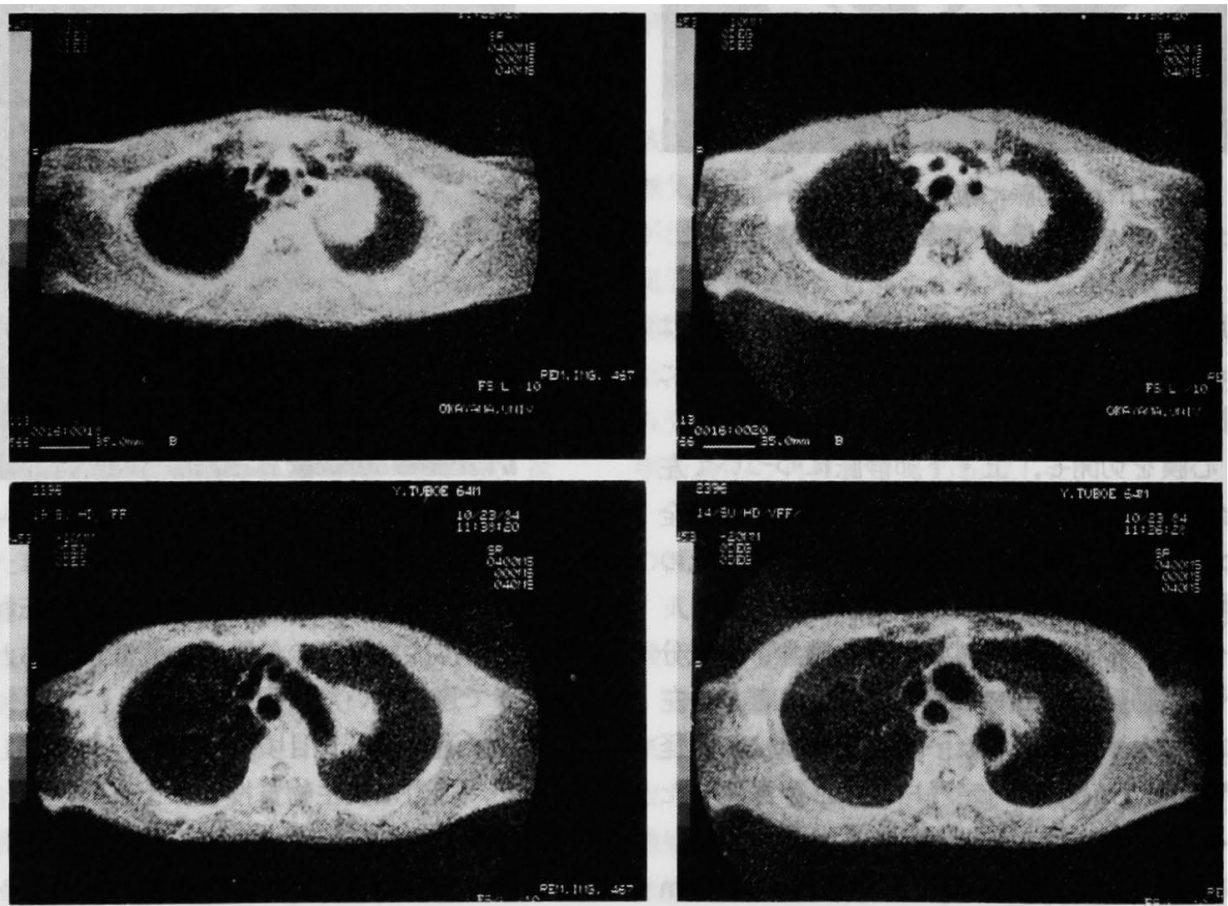

图 7 NMR-CT 像で, 腫瘤は弓部より下行大動脈にかけて瘜着しており，大動脈壁へ の漫润が疑われる. 
手術は，昭和59年11月 5 日施行され，左後側方切開 により，第 4 肋間で開胸した. 腫瘤は, $\mathrm{S}_{1,2}$ 領域にあり， 左鎖骨下動脈分枝部の大動脈壁に強固に慜着してい た．左上葉切除操作を行い，内佳 $12 \mathrm{~mm} の$ Woven Dacron グラフトを用いて上行大動脈と下行大動脈と

\section{症例 2}

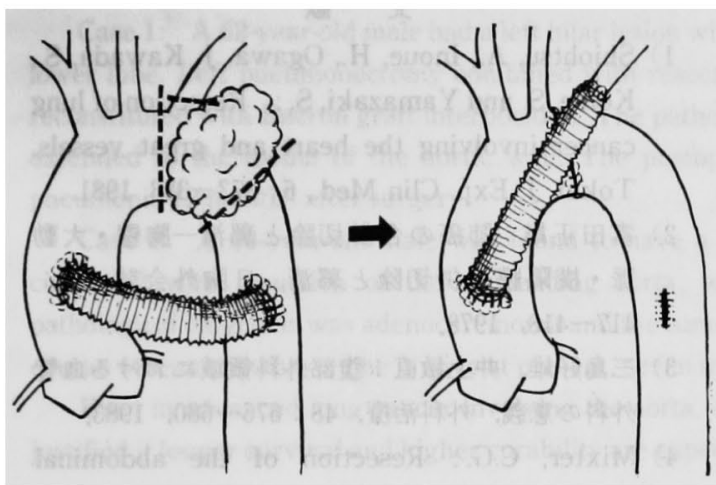

图 8 一時的パイバス下に，漫潤部大動脈を管状切除 するとともに，左鎖骨下動脈起始部を切除した。 大 動脈は端々吻合により，左鎖骨下動脈は一時的ハィ パスダラフトをそのまま用いて端々昒合として血行 再建した。

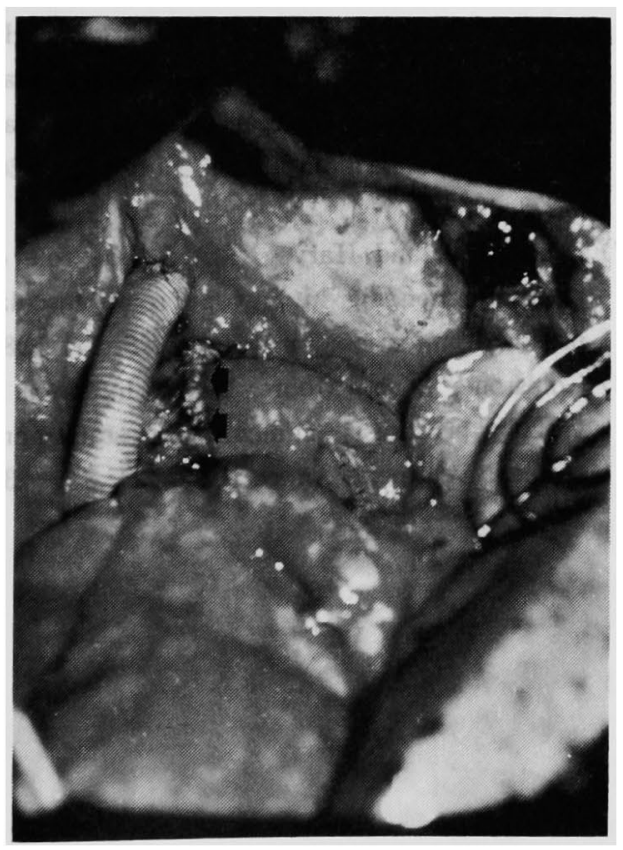

图 9 大動脈及び左鎖骨下動脈の血行再建後の栃中写 真を示す．矢印は大動脈端ヶ吻合部を示す。
の間に一時的バイパスを作製し，大動脈を $3.5 \mathrm{~cm} に わ$ たって左鎖骨下動脈の一部を含めて管状切離し，左上 葉とともに en block切除した，血行再建は，大動脈 両切離端を引き寄せ端々吻合とし，左鎖骨下動脈は， 一時的ハイパスグラフトの末梢側を切離しその部で 端々吻合した（図8，図9）。

組織所見は，低分化腺癌で，ボタロー氏管リンバ節 と葉気管支周囲リンパ節への転移を認めたが，大動脈 への浸潤はなかった。

術後経過は，残存下葉よりの空気漏れが長期間続い た他，発作性頻脈をきたしたが，対症療法により軽快 し，昭和60年1月28日退院した。術後 9 カ月経過した 現在む，元気に日常生活を送っている。

\section{考察}

胸部領域の悪性腯湯で, 大動脈壁に直接浸潤を有す る症例において，大動脈壁の一部を合併切除し，側壁 程合ないしハッッチグラフト移植を行った報告はみられ るが1), 自験例の如く，一時的パイパス下に大動脈を管 状切除し，血行再建を行った報告は極めて少ない21.大 動脈壁に浸潤を有する症例では，合併切除による根治 性の限界と人工血管感染の危険性より合併切除の適応 は少なく，たとえ合併切除しても，人工血管の使用を 避けるか，腋窩一大腿動脈ハイイハスなどを試みるべき とする意見もある゙．しかし，Mixter ら゙は，再発性結 腸癌で腹部大動脈とその分岐部に浸潤を有する症例に 対して，広沉合併切除を行い，Y型 Dacron グラフトを 用いて血行再建を行った長期生存例を報告している。 自験例に比べて，手術野の污染・周囲組織の損傷は大 きく，クラフト感染の危険性は極めて高いと考光られ る。 また，Fortner $ら^{5}$ む，膵頭部癌に対して，上腸間 膜動脈・腹腔動脈・門脈を合併切除し，一部は Dacron グラフトを用いて血行再建を行い，良好な手術成績を 報告している，肺癌における広汎合併切除は，腹部領 域に比べて, 手術野の污染, 周囲組織の損伤・壊死の 程度は少ないと考えられ，根治性が期待でき準治疾手 術が可能な限りは積極的に大動脈合併切除を試みるべ きと考える。しかし，大動脈合併切除を行う場合には， まず，大動脈壁の一部切除による側壁縫合を行らか， 症例 2 の如く，管状切除を行っても端々昒合を行 5 可 能性を追求すべきで，感染の危険性のあるパッチグラ フト移植・人工血管移植は極力避けるべきと考光る。 症例 1 では, 浸潤の範囲が大きく, 合併切除後端々吻 合が不可能となったため，止むを得ず，人工血管を使 用して血行再建を行っだのである。 
また，主要血管浸潤に対して，安全な摘除面が得ら れれば，外膜下割離により血管を温存でき，合併切除 は必要でないとする意見すある6. 確かに，血管外膜は 蹯性結合組織によりなり，筋膜・心膜の上5に漫潤に 対して一時期障壁の役割を果すと考えられる。症例 2 では，大動脈壁への浸潤が強く疑われたにもかかわら ず, 病理組織検査では，大動脈壁への漫潤はみられな かった．しかし，外膜下剥離が可能であったとしても， 病理組織的に浸潤がないといら保証はなく，剩離によ り腫膓が露出し播種する危険性もあり，根治性を追求 する限りは，合併切除が妥当であったと考光る。

血行再建を行う場合，感染に抵抗性のある自家静脈 ないし動脈を第一選択とすべきであるか，大動脈に対 しては口径が不適当であり，人工血管を使用しなけれ ばならず，感染の危険性が高い，最近，抗生物質を内・ 外面に附着させた人工血管の開発が行われており，感 染に対して強い抵抗性を有するといら報告がみられる が》，将来，感染の危惧される場合には，こらした人工 血管が使用されると考える。

また，血行再建における感染予防に関して，術前か らの予防的抗生物質投与の有効性が強調されてお $\eta^{81}$ ，広汎合併切除之血行再建を施行することが予想 される症例では，術前から予防的抗生物質投与を強力 に行らことが重要であると考える.

手術手技に関して，自験例ではいずれす，Woven Dacron グラフトを用いた一時的パイバス下に大動脈 切除を行ったが，最近広く用いられるようになった シャントチューブによる一時的バイハスる簡便な方法 と考之る。しか，症例 2 の如く，左鎖骨下動脈尚合 併切除するような症例では，中枢側吻合を上行大動脈 にとり，合併切除後は一時的バイパスを用いて，左鎖 骨下動脈に端々吻合する方法が有用であったと考え る.

大動脈の切除範用に関しては，動脈壁での属場の浸 潤様式は不明な点が多いが，症例 1 の病理組織所見で は，虑着部直下への漫潤が主で，横への浸潤はみられ ないことから，切除後の血行再建を考えた上で，最少
限度の切除範囲にとどめていいと考える.

おわりに

大動脈に漫潤を有する進行性肺癌に対して，一時的 ハヘイバス下に大動脈合併切除・血行再建を行い，良好 な手術成樍を得た 2 症例を報告した。進行性肺㿋で あっても，根治性が期待でき準治撚手術が可能と思わ れる症例に対しては，積極的に大動脈合併切除を試み るべきと考える。

\section{文献}

1) Shiohtsu, A., Inoue, H., Ogawa, J. Kawada, S., Koide, S. and Yamazaki, S. : Resection of lung cancer involving the heart and great vessels. Tokai. J. Exp. Clin Med., 6: 373-383, 1981.

2）富田正雄：肺癌の合併切除之郭清一胸壁・大動 脈・横隔膜合併切除と郭清，日胸外会誌，26： 417-418, 1978.

3）三島好雄，井上敏直：腹部外科領域における血管 外科の意義，外科治療，48：675-680，1983.

4) Mixter, C.G.: Resection of the abdominal aorta for recurrent colon cancers. Am. J. Surg., 139: 595-602, 1980.

5) Fortner, J.G.: Regional resection of cancer of the pancreas-A new surgical approach. Surgery, 73 : 307-320, 1973.

6) Morton, D.L., Eilber, F.R., Townsend, C.M., Grant, T.T., Mirra, J. and Weisenburger, T.H. Limb salvage from a multidisciplimary treat. ment approach for skeletal and soft tissue sarcoma of the extremity. Ann. Surg., 184: 268 $-278,1976$.

7) Greco, R.S. and Harvey, R.A.: The role of antibiotic bonding in prevention of vascular prosthetic infection. Ann. Surg., 195 : 171, 1982.

8) Goldstone, J. and Moore, W.S.: Infection in vascular prosthesis-clinical manifestation and surgical treatment. Am. J. Surg., 128 : 225-233, 1974. 


\title{
CONCOMITANT RESECTION AND RECONSTRUCTION OF THE DESCENDING AORTA IN ADVANCED LUNG CANCER
}

\author{
Yasuhiro SHIMIZU, Yoshio KUBO, Hideki KURIHARA, Kazuo OKANO, Setuo IMAWAKI, \\ Masaru MATSUMAE, Nobuyoshi SHIMIZU, Hatuzo UCHIDA and Shigeru TERAMOTO \\ Department of Surgery, Okayama University Medical School
}

Two patients with advanced lung cancer involving the aortic wall underwent concomitant resection and reconstruction of the aorta under a temporary bypass.

Case 1: A 62-year-old male had a left hilar lesion with severe stenosis of the main bronchus and athelectasis of the lower lobe. Left pneumonectomy combined with resection of the descending aorta was undertaken. The aorta was reconstituted with Dacron graft interposition. The pathological diagnosis was squamous cell carcinoma and the tumor extended to the media of the aortic wall. The postoperative course was uneventful. However, he died of acute pneumonia 12 months after surgery.

Case 2: A 64-year-old male was found to have a left upper lobe lesion and underwent left upper lobectormy combined with resection of the descending aorta, which was reconstituted with end-to-end anastomosis. The pathological diagnosis was adenocarcinoma and the tumor extension was restricted to the adventia. The postoperative course was uneventful and he is alive at present, seven months after surgery.

Even in advanced lung cancer involving the aorta, concomitant resection and reconstruction of the aorta may be justified if longer survival and higher curability are expected. 